\title{
PENGARUH SIKAP TERHADAP LINGKUNGAN (ENVIRONMENTAL ATTITUDE) DAN KEPRIBADIAN (BIG- FIVE PERSONALITY) TERHADAP INTENSI UNTUK BERTINDAK (INTENTION TO ACT) SISWA
}

\author{
Dewi Larasati ${ }^{1}$ I Made Putrawan ${ }^{2}$, Diana Vivanti Sigit ${ }^{3}$ \\ ${ }^{1}$ Student of Biology Education Departement of State University of Jakarta \\ ${ }^{2}$ Environmental Education Departement of State University of Jakarta \\ ${ }^{3}$ Biology Education Departement of State University of Jakarta
}

Email :larasatisjein@gmail.com,putrawan.imade@yahoo.com,dianavivanti@yahoo.com

\begin{abstract}
Global warming is one of the major challenge to humankind because this kind of environmental issue is a global issue which not only faced by one country but the whole world. The main cause of global warming is human activity. Human have to change their behavior in order to protect the environment especially the student because they're the living next generation. Behavior often occur because there is intention to do so. One's desire to act appears to be affected by a host of personality factors including environmental attitude. This study aimed to determine the effect of environmental attitude and personality on the intention to act that students have. Research conducted at SMAN 29 Jakarta on the Semester I of 2019/2020 school year. The method used is the survey with quantitative-causal causal approach and path analysis. The sample were 93 students of class X MIPA. There were three instrument used for measuring environmental attitude, personality, and intention to act with reliability of $0.774,0.786$, and 0.84 . Based on hypothesis test, it suggested that there was indirect effect between environmental attitude and intention to act via personality.As the results, it can be concluded that personality is suitable as a mediator of variables between environmental attitude and personality.
\end{abstract}

Keywords: Student, environmental attitude, personality, intention to act, path analysis. 


\section{PENDAHULUAN}

Pembangunan yang dilaksanakan saat ini di berbagai negara mengalami perkembangan pesat pada berbagai sektor. (Desfandi, 2015) Akan tetapi, masyarakat dunia juga menghadapi berbagai bencana ataupun permasalahan lingkungan yang dapat mengancam kelangsungan hidup manusia yaitu global warming. Global warming menjadi salah satu tantangan yang nyata bagi manusia. Kenaikan temperatur bumi akibat global warming dapat mencairkan gletser yang mengakibatkan kenaikan suhu air laut dan mengancam kehidupan di bumi, selain itu pemanasan global juga mengakibatkan perubahan iklim. Inter-governmental Panel on Climate Change (IPCC) menunjukkan bahwa aktivitas manusia adalah penyebab utama perubahan iklim sehingga hal ini semakin mendesak bagi setiap negara untuk mengurangi emisi gas rumah kaca secara substansial. (Huang, 2016).

Perubahan iklim di Indonesia ditandai dengan perubahan curah hujan menjadi kian tidak teratur. Perubahan iklim yang terjadi di Indonesia dapat disebabkan oleh aktivitas manusia seperti pemakaian kendaraan bermotor, industri, penggunaan listrik dan juga plastik berlebih. Manusia dianjurkan untuk mengubah pola perilaku sebagai upaya bersama dalam menjaga lingkungan. Dalam hal ini, generasi muda adalah sebagai pemegang kunci keberhasilan kondisi lingkungan masa depan karena mereka merupakan saksi dari kondisi lingkungan saat ini dan dapat dijadikan pengalaman untuk menghadapi masa depan. (de Leeuw, Valois, \& Ajzen, 2015) Namun menurut penelitian Doherty \& Clayton dalam de Leeuw, Valois, \& Ajzen (2015) walaupun sebagian generasi muda merespon ancaman lingkungan dengan meningkatkan keterlibatan untuk memperbaiki tetapi masih ada yang tidak tertarik dan tidak peduli. (de Leeuw, Valois, \& Ajzen, 2015) Kepedulian generasi muda terhadap lingkungan yang masih kurang saat ini seharusnya sudah dibentuk sejak masih dini, khususnya di sekolah karena sebagian besar waktu siswa dihabiskan di sekolah dan seharusnya di sekolah siswa juga diajarkan dan dididik untuk senantiasa peduli dan menjaga lingkungan.

Siswa merupakan generasi penerus bangsa sehingga menjaga lingkungan merupakan salah satu tanggung jawab mereka. (Putrawan, 2017) Kepedulian siswa terhadap 
lingkungan yang rendah tersebut dapat ditingkatkan melalui pendidikan lingkungan atau Environmental Education (EE). Heimlich dan Ardoin menjelaskan bahwa terdapat dua elemen yang dapat menciptakan perilaku jangka panjang yang bertanggung jawab terhadap lingkungan, satu diantaranya adalah Pendidikan lingkungan, yang dapat diasumsikan sebagai informasi yang didapat dan akan memengaruhi seseorang dalam berperilaku atau bertindak dengan bijak. Seperti misalnya jika seeorang memahami apa yang dapat mencemari air dan apa yang dapat merusak tanaman, mereka dapat menggunakan informasi tersebut dalam berbagai situasi sehingga menghasilkan perilaku yang tidak merusak. (Heimlich \& Ardoin, 2008).

Environmental education (EE) oleh Harold \& Volk mendeskripsikan bahwa meningkatnya pengetahuan menuntun pada sikap positif dimana sikap positif ini menuntun pada keinginan bertindak untuk menjadikan lingkungan yang lebih baik. Dapat diasumsikan bahwa jika siswa mendapat banyak pengetahuan mengenai lingkungan maka mereka akan lebih sadar terhadap lingkungan dan permasalahannya sehingga mereka termotivasi untuk bersikap positif terhadap lingkungan.(Hungerford \& Volk, 1990) Menurut model Responsible Environmental Behavior Hines, Hungerford dan Tomera terdapat banyak faktor yang dapat memprediksi perilaku bertanggung jawab terhadap lingkungan salah satu nya intention to act yaitu intensi seseorang untuk bertindak. Intention to act atau intensi seseorang untuk bertindak dapat dipengaruhi oleh faktor-faktor kepribadian (personality factors) seperti locus of control, attitude, dan personal responsibility. (Hines, Hungerford, \& Tomera, 1987). 


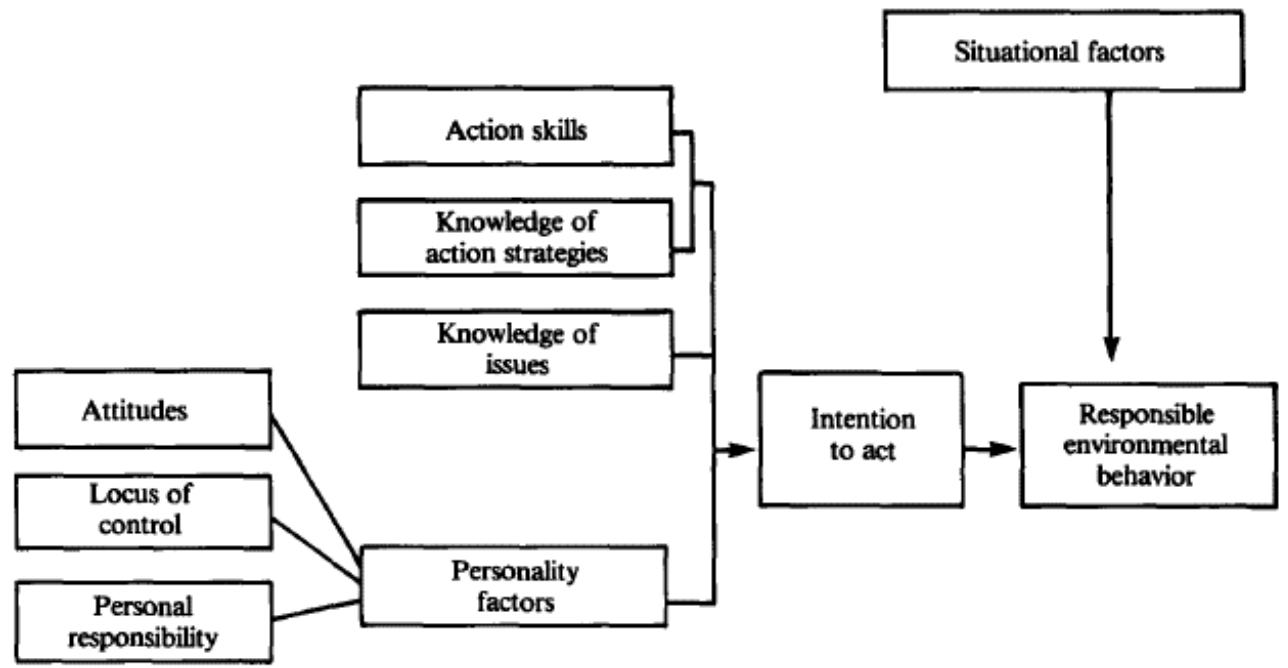

Gambar 1. Model Perilaku Bertanggung Jawab terhadap Lingkungan oleh Hines, Hungerford, dan Tomera (1987)

Intention atau Intensi sering dilihat sebagai komponen konatif dari sikap (kecenderungan berperilaku dan belum tentu akan diterapkan dalam bentuk perilaku yang sesuai), sering diasumsikan bahwa komponen konatif berhubungan dengan komponen afektif sikap. (Ajzen \& Fishbein, 2010). Menurut Ajzen \& Fishbein (1991) terdapat dua faktor yang menentukan intensi yaitu attitude dan subjective norm. Komponen attitude merujuk pada sikap seseorang terhadap suatu perilaku, subjective norm berhubungan dengan kepercayaan seseorang sehingga dapat menentukan apakah ia akan melakukan perilaku tersebut atau tidak. (Fatria, Putrawan, \& Artanti, 2019).

Seseorang harus memiliki keinginan untuk bertindak dimana keinginan tersebut dapat dipengaruhi oleh personality factors atau faktor-faktor kepribadiann seperti locus of control, attitude, dan personal responsibility. Seseorang yang memiliki locus of control internal, attitude yang positif terhadap lingkungan dan memliki rasa kewajiban terhadap lingkungan akan membangun keinginan untuk bertindak positif terhadap lingkungan. (Hines, Hungerford, \& Tomera, 1987; Putrawan \& Ananda, 2019). 
Personality Menurut McRae dan Costa dibagi menjadi lima dimensi yang disebut the big five personality. Kelima faktor tersebut terbukti secara reliabilitas dan validitas yang relatif stabil. Pada tahun 1981, Lewis Goldberg meninjau penelitian yang ada dan takjub terhadap konsistensi hasil dari kelima faktor tersebut. Ia mengusulkan bahwa semua model yang dibuat untuk mengetahui kepribadian seseorang harus mencakup tingkat tertentu seperti model big five. "Big" dalam big five merujuk pada masing-masing faktor menggolongkan sejumlah besar sifat yang lebih spesifik. Kelima faktor ini antara lain: Openness $(\mathrm{O})$, Conscientiousness $(\mathrm{C})$, Extraversion (E), Agreeableness (A), dan Neuroticism (N). Faktor tersebut lebih mudah diingat dengan menyingkatnya menjadi OCEAN. Arti dari masing-masing faktor dapat dilihat dengan mengkaji sifat yang menggambarkan suatu individu yang dapat dilihat pada Tabel 1. (Cervone \& Pervin, 2011; Putrawan, 2017)

Tabel 1. Lima Faktor Personaltiy "Big Five" oleh McRae dan Costa

\begin{tabular}{|c|c|c|}
\hline Characteristics of the High Scorer & Trait Scales & Characteristics of the Low Scorer \\
\hline $\begin{array}{l}\text { NEUROTICISM (N) } \\
\text { Worrying, nervous, emotional, } \\
\text { insecure, inadequate, } \\
\text { hypochondriacal }\end{array}$ & $\begin{array}{l}\text { Assesses adjustment versus } \\
\text { emotional instability. Identifies } \\
\text { individuals prone to psychological } \\
\text { distress, unrealistic ideas, } \\
\text { excessive cravings or urges, and } \\
\text { maladaptive coping responses }\end{array}$ & $\begin{array}{l}\text { Calm, relaxed, unemotional, } \\
\text { hardy, secure, self-satisfied }\end{array}$ \\
\hline $\begin{array}{l}\text { EXTRAVERSION (E) } \\
\text { Sociable, active, talkative, } \\
\text { person-oriented, optimistic, } \\
\text { fun-loving, affectionate }\end{array}$ & $\begin{array}{l}\text { Assesses quantity and intensity of } \\
\text { interpersonal interaction; activity } \\
\text { level; need for stimulation; and } \\
\text { capacity for joy }\end{array}$ & $\begin{array}{l}\text { Reserved, sober, unexuberant, } \\
\text { aloof, task-oriented, retiring, } \\
\text { quiet }\end{array}$ \\
\hline $\begin{array}{l}\text { OPENNESS }(\mathrm{O}) \\
\text { Curious, broad interests, } \\
\text { creative, original, imaginative, } \\
\text { untraditional }\end{array}$ & $\begin{array}{l}\text { Assesses proactive seeking and } \\
\text { appreciation of experience for its } \\
\text { own sake; toleration for and } \\
\text { exploration of the unfamiliar }\end{array}$ & $\begin{array}{l}\text { Conventional, down-to-earth, } \\
\text { narrow interests, unartistic, } \\
\text { unanalytical }\end{array}$ \\
\hline $\begin{array}{l}\text { AGREEABLENESS (A) } \\
\text { Soft-hearted, good-natured, } \\
\text { trusting, helpful, forgiving, } \\
\text { gullible, straightforward }\end{array}$ & $\begin{array}{l}\text { Assesses the quality of one's } \\
\text { interpersonal orientation along a } \\
\text { continuum from compassion to } \\
\text { antagonism in thoughts, feelings, } \\
\text { and actions }\end{array}$ & $\begin{array}{l}\text { Cynical, rude, suspicious, } \\
\text { uncooperative, vengeful, ruth- } \\
\text { less, irritable, manipulative }\end{array}$ \\
\hline $\begin{array}{l}\text { CONSCIENTIOUSNESS (C) } \\
\text { Organized, reliable, } \\
\text { hard-working, self-disciplined, } \\
\text { punctual, scrupulous, neat, } \\
\text { ambitious, persevering }\end{array}$ & $\begin{array}{l}\text { Assesses the individual's degree of } \\
\text { organization, persistence, and } \\
\text { motivation in goal-directed } \\
\text { behavior; contrasts dependable, } \\
\text { fastidious people with those who } \\
\text { are lackadaisical and sloppy }\end{array}$ & $\begin{array}{l}\text { Aimless, unreliable, lazy, } \\
\text { careless, lax, negligent, } \\
\text { weak-willed, hedonistic }\end{array}$ \\
\hline
\end{tabular}


Intention to act dapat dipengaruhi oleh environmental attitude dan personality. Newhouse (1990) mendefinisikan attitude sebagai perasaan positif dan negatif terhadap suatu individu, objek, atau masalah. Hal yang erat kaitannya dengan sikap adalah kepercayaan (belief) yang merujuk pada informasi atau pengetahuan seseorang mengenai suatu individu, objek, atau masalah. Sedangkan Environmental attitude menurut Hans, dkk. dalam Lee \& Jan (2015) merujuk pada sikap seseorang terhadap suatu objek atau lingkungan. Milfont \& Duckitt (2010) mendefiniskan environmental attitude sebagai ekspresi kecenderungan psikologis seseorang dalam mengevaluasi lingkungan dengan tingkatan besaran dukungan terhadap lingkungan.

Sama halnya dengan ciri kepribadian, sikap merupakan konstruksi hipotesis yang tidak dapat diamati secara langsung namun melalui respon yang terukur. Respon tersebut harus merefleksikan evaluasi atau penilaian positif dan negatif dari sikap terhadap suatu objek. Respon ini dapat dibedakan dalam beberapa kelompok dan dibedakan antara respon perilaku yang dilakukan di tempat umum ataupun di tempat sendiri. Plato membagi respon sikap dalam beberapa kategori yaitu: kognitif, afektif, dan konatif. Respon kognitif merefleksikan persepsi, pemikiran, kepercayaan terhadap suatu objek. Respon afektif merupakan evaluasi perasaan seseorang terhadap suatu objek psikologi seperti misalnya seseorang yang memiliki perasaan senang terhadap lingkungan dapat mengarahkan mereka dalam bersikap positif terhadap lingkungan sedangkan respon konatif berhubungan dengan kecenderungan berperilaku, niat, komitmen sehubungan dengan objek psikologi tersebut. Seperti misalnya jika seseorang memiliki sikap positif terhadap lingkungan maka ia cenderung untuk berperilaku positif terhadap lingkungan. (Ajzen, 2005).

Environmental attitude dan personality memberikan gambaran terhadap perilaku seseorang terhadap lingkungan. Environmental attitude merupakan disposisi seseorang sebelum bertindak terhadap lingkungan dan personality merupakan karakteristik seseorang dalam merespon dan berinteraksi dengan lingkungan maupun lain maka environmental attitude yang dimiliki seseorang akan sesuai dengan personality yang ia miliki sehingga akan tercermin intention to act seseorang. 
Berdasarkan pemaparan latar belakang diatas maka dipandang perlu melakukan penelitian tentang pengaruh environmental attitude dan personality terhadap intention to act siswa terutama untuk mengetahui pengaruh langsung environmental attitude terhadap intention to act karena pada model Hines (1987) belum diketahui ada atau tidaknya pengaruh langsung pada variabel tersebut.

Berdasarkan uraian di atas, maka rumusan masalah pada penelitian ini adalah: (1) Apakah Environmental attitude berpengaruh langsung terhadap personality siswa?; (2) Apakah personality berpengaruh langsung terhadap terhadap intention to act siswa?; (3) Apakah Environmental attitude berpengaruh langsung terhadap intention to act siswa?; (4) Apakah Environmental attitude berpengaruh tidak langsung terhadap intention to act siswa melalui personality siswa?. Penelitian ini bertujuan untuk mengetahui pengaruh environmental attitude dan personality terhadap intention to act yang dimiliki siswa.

\section{METODOLOGI}

Metode penelitian yang digunakan adalah metode survei yang bersifat kausal. Penelitian yang dilakukan termasuk kedalam jenis penelitian kuantitatif dengan menggunakan analisis jalur (path analysis) yang dipilih untuk menganalisis pola hubungan sebab akibat antar variabel dengan tujuan untuk mengetahui pengaruh secara langsung maupun tidak langsung antara variabel eksogen dan endogen. Penelitian ini mempunyai tiga variabel, yaitu $\mathrm{X}_{1}$ (environmental attitude) dan $\mathrm{X}_{2}$ (personality) sebagai variabel eksogen serta $\mathrm{X}_{3}$ (intention to act) sebagai variabel endogen. Model hipotetik dari penelitian ini dapat digambarkan sebagai berikut:

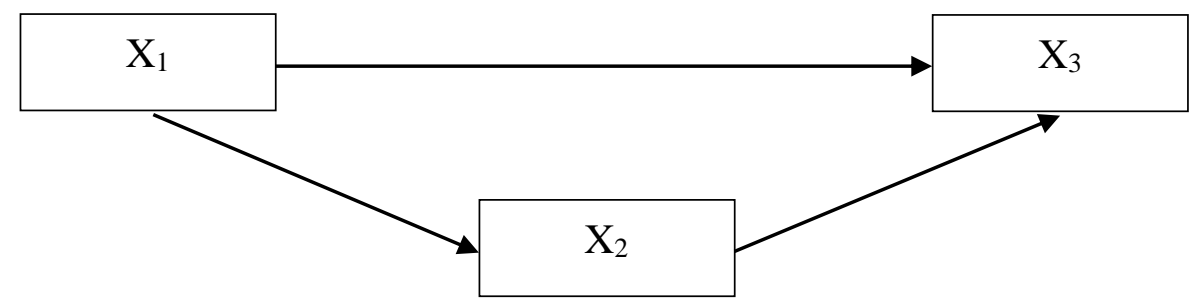

Gambar 2. Model Hipotetik 
Dalam penelitian ini populasi targetnya adalah seluruh siswa SMA kelas $X$ MIPA di Provinsi DKI Jakarta. Pengambilan sampel dalam penelitian ini dilakukan dengan cara multistage random sampling (teknik pengambilan sampel secara bertahap). (1) purposive sampling, (2) cluster random sampling, (3) simple random sampling. responden dalam penelitian ini adalah sebanyak 96 siswa kelas X MIPA SMA Negeri, dari 96 siswa dipilih sebanyak 93 siswa secara simple random sampling.

Instrumen yang digunakan dalam penelitian berupa opinioner yang diberikan kepada responden yaitu instrumen intention to act, personality, dan environmental attitude. Jumlah butir instrumen intention to act adalah 30 butir dan tidak ada butir yang tidak valid dengan koefisien reliabilitas kelas uji coba sebesar 0,855 dan reliabilitas sampel sebesar 0,84 . Jumlah butir instrumen personality adalah 30 butir dan 6 butir tidak valid serta koefisien reliabilitasnya butir lengkap sebesar 0,714, butir valid sebesar 0,737, dan reliabilitas sampel sebesar 0,786. Jumlah butir instrumen environmental attitude adalah 33 dan 3 butir tidak valid dengan koefisien reliabilitas butir lengkap sebesar 0,771, reliabilitas butir valid sebesar 0,797, dan reliabilitas sampel sebesar 0,774 .

\section{HASIL DAN PEMBAHASAN}

Berdasarkan hasil uji signifikansi dan linearitas environmental attitude $\left(\mathrm{X}_{1}\right)$ terhadap personality $\left(\mathrm{X}_{2}\right)$, diperoleh konstanta regresi $\mathrm{a}=29,645$ dan koefisien regresi $b=0,523$. Dengan demikian menghasilkan persamaan regresi sederhana $\hat{X}_{2}$ $=29,645+0,523 X_{1}$. Untuk mengetahui pengaruh langsung antar variabel maka dilakukan perhitungan koefisien jalur dengan bantuan aplikasi SPSS ver. 26. Hasil perhitungan dapat dilihat pada tabel 3 . berikut: 
Tabel 3. Koefisien Jalur Environmental Attitude $\left(\mathrm{X}_{1}\right)$ terhadap Personality $\left(\mathrm{X}_{2}\right)$

\begin{tabular}{|c|c|c|c|c|c|c|c|c|}
\hline \multirow[b]{2}{*}{ Model } & \multicolumn{2}{|c|}{$\begin{array}{l}\text { Unstandardized } \\
\text { Coefficients }\end{array}$} & \multirow{2}{*}{$\begin{array}{l}\text { Standardized } \\
\text { Coefficients } \\
\text { Beta }\end{array}$} & \multirow[b]{2}{*}{$\mathrm{T}$} & \multirow[b]{2}{*}{$t_{\text {tabel }}$} & \multicolumn{2}{|c|}{ Correlations } & \multirow[b]{2}{*}{ Part } \\
\hline & B & Std. Error & & & & $\begin{array}{l}\text { Zero- } \\
\text { order }\end{array}$ & Partial & \\
\hline 1 (Constant) & 29,645 & 13,566 & & 2,185 & & & & \\
\hline EA &, 523 & ,098 & ,489 & $5,354 *$ & 2,63 & ,489 & ,489 & ,489 \\
\hline
\end{tabular}

Dari hasil perhitungan koefisien jalur $\mathrm{X}_{1}$ terhadap $\mathrm{X}_{2}$ diperoleh hasil $\mathrm{Phi}_{21}$ sebesar 0,489 dengan $\mathrm{t}_{\text {hitung }}=5,354>\mathrm{t}_{\text {tabel }}(0,01 ; 91)=2,63094$, yang artinya terdapat pengaruh langsung antara environmental attitude terhadap personality yang signifikan. Berdasarkan hasil uji signifikansi dan linearitas personality $\left(\mathrm{X}_{2}\right)$ terhadap intention to act $\left(\mathrm{X}_{3}\right)$, diperoleh konstanta regresi $\mathrm{a}=7,244$ dan koefisien regresi $\mathrm{b}=$ 0,871. Dengan demikian menghasilkan persamaan regresi sederhana $\hat{X}_{3}=7,244+$ $0,871 \mathrm{X}_{2}$. Untuk mengetahui pengaruh langsung antar variabel maka dilakukan perhitungan koefisien jalur dengan bantuan aplikasi SPSS ver. 26. Hasil perhitungan dapat dilihat pada tabel 4. berikut:

Tabel 4. Koefisien Jalur Personality $\left(\mathrm{X}_{2}\right)$ terhadap Intention to Act $\left(\mathrm{X}_{3}\right)$

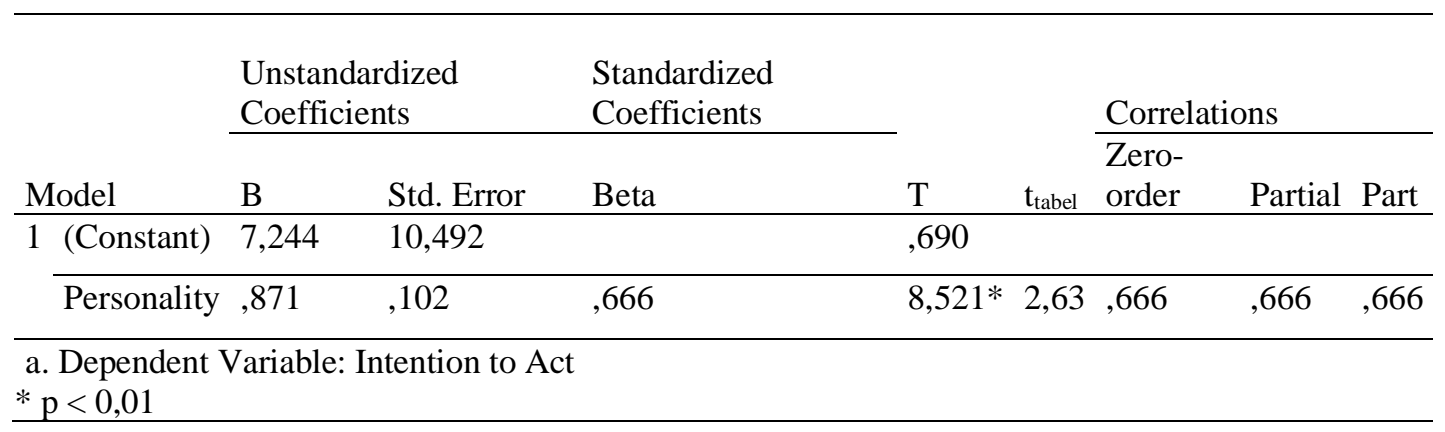

Dari hasil perhitungan koefisien jalur $\mathrm{X}_{2}$ terhadap $\mathrm{X}_{3}$ diperoleh hasil $\mathrm{Phi}_{32}$ sebesar 0,666 dengan $t_{\text {hitung }}=8,521>t_{\text {tabel }}(0,01 ; 91) 2,63$, yang artinya terdapat pengaruh langsung antara personality terhadap intention to act yang signifikan. Berdasarkan hasil uji signifikansi dan linearitas environmental attitude $\left(\mathrm{X}_{1}\right)$ terhadap intention to act $\left(\mathrm{X}_{3}\right)$, diperoleh konstanta regresi $\mathrm{a}=-2,494$ dan koefisien regresi $\mathrm{b}=$ 0,713. Dengan demikian menghasilkan persamaan regresi sederhana $\hat{X}_{3}=-2,494+$ 
$0,713 \mathrm{X}_{1}$. Untuk mengetahui pengaruh langsung antar variabel maka dilakukan perhitungan koefisien jalur dengan bantuan aplikasi SPSS ver. 26. Hasil perhitungan dapat dilihat pada tabel 5. berikut:

Tabel 5. Koefisien Jalur Environmental Attitude $\left(\mathrm{X}_{1}\right)$ terhadap Intention to Act $\left(\mathrm{X}_{3}\right)$

\begin{tabular}{|c|c|c|c|c|c|c|c|c|}
\hline \multirow[b]{2}{*}{ Model } & \multicolumn{2}{|c|}{$\begin{array}{l}\text { Unstandardized } \\
\text { Coefficients }\end{array}$} & \multirow{2}{*}{$\begin{array}{l}\text { Standardized } \\
\text { Coefficients } \\
\text { Beta }\end{array}$} & \multirow[b]{2}{*}{$\mathrm{T}$} & \multirow[b]{2}{*}{$t_{\text {table }}$} & \multicolumn{3}{|c|}{ Correlations } \\
\hline & B & Std. Error & & & & $\begin{array}{l}\text { Zero- } \\
\text { order }\end{array}$ & Partial & Part \\
\hline 1 (Constant) & $-2,494$ & 17,501 & &,- 142 & & & & \\
\hline EA & ,713 & 126 & ,510 & $5,652 *$ & 2,63 & ,510 & ,510 & ,510 \\
\hline
\end{tabular}
a. Dependent Variable: Intention to Act $* \mathrm{p}<0,01$

Dari hasil perhitungan koefisien jalur $\mathrm{X}_{1}$ terhadap $\mathrm{X}_{3}$ diperoleh hasil $\mathrm{Phi} \mathrm{i}_{31}$ sebesar 0,510 dengan $t_{\text {hitung }}=5,652>\mathrm{t}_{\text {tabel }}(0,01 ; 91)=2,63$, yang artinya terdapat pengaruh langsung antara environmental attitude terhadap intention to act yang signifikan.

Berdasarkan hasil perhitungan pada poin 1, 2, dan 3 diatas maka dapat digambarkan model empirik seperti pada gambar dibawah ini:

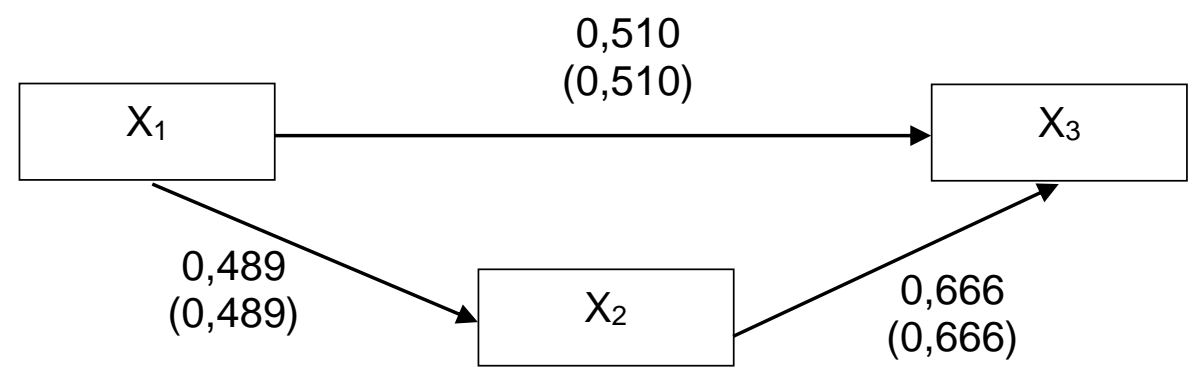

Gambar 3. Model Empirik Penelitian

Keterangan:

$\mathrm{X}_{1}=$ Environmental Attitude

$\mathrm{X}_{2} \quad=$ Personality

$\mathrm{X}_{3} \quad=$ Intention to act

Pengaruh variabel environmental attitude terhadap variabel intention to act melalui variabel personality dapat diperoleh dengan menggunakan rumus sebagai berikut : 
$\mathrm{Phi}_{31.2}=\left(\mathrm{Phi}_{21}\right)\left(\mathrm{Phi}_{32}\right)$

$$
\begin{aligned}
& =(0,489)(0,666) \\
& =0,326
\end{aligned}
$$

Kemudian dihitung t menggunakan uji t-parsial:

$$
\begin{aligned}
\mathrm{t} & =\frac{\text { phi31.2 } \sqrt{n-3}}{\sqrt{1-(p h i 31.2)^{2}}} \\
& =\frac{0,326 \sqrt{90}}{\sqrt{1-(0,326)^{2}}} \\
& =\frac{5,417}{0,945} \\
& =5,732
\end{aligned}
$$

Hasil perhitungan di atas menunjukkan bahwa $t_{\text {hitung }} 5,732>t_{\text {tabel }}(0,01 ; 91)=$ 2,63, yang artinya terdapat pengaruh tidak langsung $X_{1}$ melalui $X_{2}$ terhadap $X_{3}$ yang signifikan. Dengan demikian dapat disimpulkan bahwa meningkatnya environmental attitude dapat meningkatkan intention to act secara langsung dan secara tidak langsung melalui meningkatnya personality. Adapun berdasarkan hasil perhitungan dapat dirangkum hasil pengujian hipotesis pada tabel 6. berikut ini:

Tabel 6. Rangkuman Hasil Pengujian Hipotesis

\begin{tabular}{cccc}
\hline Hipotesis Statistika & Koefisien Jalur & $\mathbf{t}_{\text {hitung }}$ & $\mathbf{t}_{\text {tabel }}$ \\
\hline $\mathrm{H}_{0}: \rho_{21}=0$ & 0,489 & 5,354 & 2,63 \\
$\mathrm{H}_{1}: \rho_{21}>0$ & 0,666 & 8,521 & 2,63 \\
\hline $\begin{array}{l}\mathrm{H}_{0}: \rho_{32}=0 \\
\mathrm{H}_{1}: \rho_{32}>0\end{array}$ & 0,510 & 5,652 & 2,63 \\
\hline $\begin{array}{l}\mathrm{H}_{0}: \rho_{31}=0 \\
\mathrm{H}_{1}: \rho_{31}>0\end{array}$ & 0,326 & 5,732 & 2,63 \\
\hline $\begin{array}{l}\mathrm{H}_{0}: \rho_{31.2}=0 \\
\mathrm{H}_{1}: \rho_{31.2}>0\end{array}$ & & & \\
\hline
\end{tabular}

Berdasarkan hasil pengujian hipotesis pertama menunjukkan bahwa terdapat pengaruh langsung environmental attitude terhadap personality siswa yang signifikan. Environmental attitude merupakan penilaian positif negatif siswa terhadap lingkungan sehingga dapat mempengaruhi personality siswa dalam merespon dan berinteraksi dengan lingkungan.

Sesuai dengan teori attitude yang dikemukakan oleh Plato dalam Ajzen (2005) bahwa environmental attitude merupakan evaluasi positif negatif dari respon 
kognitif, afektif, dan konatif yang membuat seseorang dapat bersikap berbeda dari orang lain. Environmental attitude memberikan peran yang sangat penting terhadap lahirnya personality karena menurut Hines, Hungerford, dan Tomera (1987) attitude merupakan salah satu faktor yang membentuk personality. Seseorang dapat memiliki personality terhadap lingkungan yang tinggi apabila seseorang tersebut memiliki environmental attitude yang tinggi.

Hasil penelitian serupa dengan penelitian yang dilakukan oleh Damianus Daikoban, I Made Putrawan, \& Diana Vivanti Sigit (2019) menunjukan bahwa environmental attitude berkorelasi positif dan signifikan terhadap personality. Hasil penelitian yang dilakukan juga sesuai dengan teori personality menurut Murray dalam Schultz (2004) yang mengatakan bahwa segala sesuatu yang memengaruhi kepribadian ada di otak, termasuk keadaan perasaan, kenangan sadar dan tak sadar, keyakinan, sikap, ketakutan, dan nilai. Attitude atau sikap itu sendiri dapat terbentuk karena adanya evaluasi dari keyakinan, perasaan, dan kecenderungan untuk bertindak. (Ajzen, 2005).

Environmental attitude dapat diketahui ketika siswa memiliki ketiga respon sikap yang positif terhadap lingkungan yaitu memiliki keyakinan atau pengetahuan bahwa menjaga lingkungan merupakan suatu kewajiban penting bagi semua manusia lalu memiliki perasaan senang dalam melestarikan lingkungan dan memiliki kecenderungan bertindak untuk dapat menjaga dan melestarikan lingkungan maka hal tersebut dapat mempengaruhi personality siswa dalam merespon dan berinteraksi dengan lingkungannya secara positif.

Berdasarkan hasil pengujian hipotesis kedua menunjukkan bahwa terdapat pengaruh langsung personality terhadap intention to act siswa yang signifikan. Hasil penelitian ini sesuai dengan model Hines (1987), di mana faktor-faktor yang dapat mempengaruhi intention to act yaitu salah satu nya faktor personality. Intention to act disini merupakan intensi untuk bertindak positif terhadap lingkungan baik itu intensi untuk mendaur ulang barang, menaati aturan lingkungan, mengurangi penggunaan energi, mengonsumsi produk ramah lingkungan, dan intensi untuk aktif dalam kegiatan lingkungan. 
Hasil penelitian yang dilakukan sesuai dengan penelitian yang dilakukan oleh Cameron Brick \& Gary J. Lewis (2014) bahwa personality dapat mempengaruhi intensi untuk mengurangi penggunaan energi terutama pada dimensi openness dan conscientiousness. Seseorang yang memiliki pola personality berbeda akan memiliki pola berperilaku yang berbeda pula. (Putrawan, 2018). Personality menentukan pembentukan pola berperilaku berkaitan dengan respon yang ditampilkan dalam menghadapi suatu situasi di lingkungan. (Poškus, 2017)

Penelitian yang dilakukan oleh Mykolas S. Poškus (2017) menyatakan bahwa personality berpengaruh terhadap behavioral intention siswa SMA terutama seseorang yang memiliki skor tinggi pada dimensi openness to experience dan conscientiousness cenderung memiliki skor tinggi pada behavioral intention atau intensi untuk berperilaku terutama keinginan dalam mendaur ulang barang, mengurangi penggunaan energi dan air. Penelitian yang dilakukan oleh I Made Putrawan dan Lisa Dwi Ningtyas (2019) juga menyatakan bahwa personality secara signifikan mempengaruhi perilaku pro lingkungan.

Personality adalah sifat atau karakteristik siswa dalam merespon dan berinteraksi dengan individu lain atau lingkungannya. Setiap siswa memiliki respon yang berbeda-beda terhadap lingkungan, baik dalam hal pemeliharaan, pengelolaan maupun pelestarian lingkungan. Perbedaan respon itulah yang menggambarkan bahwa setiap orang memiliki personality atau kepribadiannya masing-masing. Personality siswa akan menjadi karakteristik tersendiri yang dimiliki siswa tersebut, begitupun dalam cara merespon keadaan lingkungan. Personality siswa sudah dimiliki karena adanya faktor biologis, meskipun dapat berubah karena faktor lingkungan, tetapi karakteristik khas yang diwariskan secara biologis akan tetap ada. Hal tersebut membuktikan bahwa personality secara langsung sangat signifikan mempengaruhi intention to act.

Berdasarkan hasil pengujian hipotesis ketiga menunjukkan bahwa environmental attitude secara langsung dapat mempengaruhi intention to act siswa yang signifikan. Ketika seseorang siswa memiliki nilai environmental attitude yang tinggi maka secara langsung siswa tersebut memiliki intention to act yang tinggi 
juga. Semakin tinggi nilai environmental attitude siswa maka semakin tinggi pula intention to act yang dimilikinya.

Hasil penelitian ini sesuai dengan penelitian yang dilakukan oleh Debra S. Levine \& Michael J Strube (2012) yang menyatakan bahwa explicit attitude merupakan prediktor intention yang kuat dimana intention itu sendiri merupakan variabel yang dapat memprediksi behavior dengan kuat. Dalam penelitian ini yang diuji pengaruhnya terhadap intention adalah attitude dimana attitude dalam penelitian ini dibedakan menjadi implicit dan explicit attitude. Sikap eksplisit merupakan sikap yang dimiliki secara sadar dan dapat diungkapkan dengan mudah sedangkan sikap implisit merupakan sikap yang tidak disengaja, tak terkendali dan tidak disadari. (Levine \& Strube, 2012). Hasil penelitian yang didapat memberikan kontribusi teoritik pada model Hines (1987) dimana diketahui adanya pengaruh langsung environmental attitude terhadap intention to act yang signifikan.

Penelitian mengenai pengaruh langsung environmental attitude terhadap intention to act juga telah dilakukan sebelumnya oleh Achchuthan S. \& Velnampy T. (2016) namun berbeda objek yang diteliti yaitu green consumerism pada konsumen di Sri Lanka. Hasil penelitian menunjukkan bahwa environmental attitude berpengaruh signifikan terhadap intensi untuk membeli produk ramah lingkungan, hal ini berarti penilaian positif seseorang terhadap lingkungan (environmental attitude) dari segi afektif, kognitif, dan konatif yang membuat seseorang tersebut lebih memilih produk yang ramah lingkungan.

Intention to act atau keinginan siswa untuk bertindak positif terhadap lingkungan dapat ditentukan oleh environmental attitude atau sikap positif siswa terhadap lingkungan. Siswa yang memiliki pengetahuan bahwa menjaga lingkungan itu penting, merasa senang dalam menjaga lingkungan, dan memiliki niat untuk menjaga lingkungan maka siswa tersebut memiliki sikap positif terhadap lingkungan dimana bila siswa sudah memiliki sikap positif terhadap lingkungan maka ia akan memiliki keinginan untuk bertindak positif terhadap lingkungan. 
Berdasarkan hasil pengujian hipotesis keempat menunjukkan bahwa environmental attitude secara tidak langsung dapat mempengaruhi intention to act melalui personality. Siswa yang memiliki environmental attitude tinggi maka secara tidak langsung siswa tersebut memiliki intention to act melalui personality yang tinggi. Hasil penelitian ini sesuai dengan model Hines (1987), di mana faktor-faktor yang dapat memengaruhi intention to act yaitu faktor personality terutama attitude, locus of control, dan personal responsibility.

Hasil penelitian sesuai dengan teori yang dikemukakan oleh Ajzen (2005) yaitu bahwa attitude dan personality diasumsikan sebagai predisposisi atau kecenderungan untuk berperilaku yang relevan sesuai dengan respon attitude dan personality yang dimunculkan. Penelitian mengenai pengaruh personality sebagai variabel mediator antara environmental attitude dan intention to act siswa masih jarang dilakukan. Penelitian yang mirip dengan penelitian yang dilakukan adalah penelitian oleh Ryan E. Rhodes, Kerry S. Courneya, \& Leslie A. Hayduk (2002), perbedaan terletak pada objek yang diteliti keinginan untuk berolahraga pada mahasiswa strata satu. Pada penelitian didapatkan hasil yang serupa bahwa personality dapat menjad variabel mediator antara attitude dan intention terutama pada dimensi personality conscientiousness yaitu merepresentasikan orang yang berhati-hati dan dapat diandalkan.

Intention to act dapat ditentukan oleh kemauan seorang siswa tergantung bagaimana environmental attitude dan personality siswa tersebut. Pengaruh environmental attitude terhadap intention to act dapat terjadi secara langsung maupun tidak langsung melalui personality. Hal ini dikarenakan personality siswa dapat menentukan sifat yang muncul dari environmental attitude siswa untuk menentukan intention to act.

Hasil penelitian memberikan informasi baru yang dapat dikembangakan untuk diteliti selanjutnya, karena belum ada penelitian yang menjadikan personality sebagai variabel mediator antara environmental attitude dan intention act siswa sekolah menengah atas. Environmental attitude dan Personality dapat menjadi suatu faktor yang menentukan intention to act siswa karena keinginan siswa untuk 
berperilaku dapat terbentuk dalam diri siswa sesuai dengan sikap maupun kepribadian (personality) yang dimilikinya. Pengetahuan, perasaan, dan kecenderungan bertindak siswa terhadap masalah lingkungan yang adapun dapat memunculkan intention to act karena secara alamiah seorang individu ingin berperilaku positif ataupun berperilaku menjaga lingkungan bila ia memahami masalah-masalah lingkungan yang terjadi dan memiliki kepribadian yang positif terhadap lingkungan.

\section{KESIMPULAN}

Beberapa temuan dalam penelitian ini adalah sebagai berikut : (1) Environmental attitude berpengaruh langsung terhadap personality secara signifikan; (2) Personality berpengaruh langsung terhadap intention to act secara signifikan; (3) Environmental attitude berpengaruh langsung terhadap intention to act secara signifikan; (4) Environmental attitude berpengaruh tidak langsung terhadap intention to act melalui personality secara signifikan.

Berdasarkan temuan temuan tersebut dapat disimpulkan bahwa environmental attitude dan personality dapat mempengaruhi intention to act siswa. Setiap siswa dapat memiliki intention to act sesuai dengan environmental attitude dan personality yang dimilikinya. Environmental attitude berpengaruh tidak langsung terhadap intention to act melalui personality secara signifikan sehingga personality baik dijadikan sebagai mediator variabel antara environmental attitude dengan intention to act.

\section{REFERENSI}

Achchuthan, S. \& Thirunavukkarasu, V. (2016). "Enhancing Purchase Intentions Towards Sustainability: The Influence of Environmental Attitude, Perceived Consumer Effectiveness, Health Consciousness and Social Influence". Journal of Research for Consumers, 30, 79-105.

Ajzen, I. (2005). Attitudes, Personality, and Behavior. Maidenhead: Open University Press McGraw-Hill. 
Ajzen, I \& Fishbein, M. (2010). Predicting and changing behavior: The Reasoned Action Approach. New York: Psychology Press Taylor \& Francis Group.

Ajzen, I \& Fishbein, M., (1991). Theory of planned behavior. Organizational Behavior and Human Decision Processes, 50, (2), 179-211. https://doi.org/10.1016/0749-5978(91)90020-T

Brick, Cameron, and Gary J. Lewis. (2014). "Unearthing the 'Green' Personality: Core Traits Predict Environmentally Friendly Behavior." Environment and Behavior, 48, (5), 635-658. https://doi.org/10.1177/0013916514554695

Cervone, D. \& Pervin, L. A. (2011). Personality: Theory and Research Tweltfh Edition. New Jersey: John Wiley \& Sons, Inc.

Daikoban, D., Putrawan, I.M., \& Sigit, D.V. (2019). "Students' personality in Environmental Model based on students' Attitude, LOC and Personal Responsiblity". Test Engineering and Management, 81, 5013-5021.

De Leeuw, Astrid, Pierre Valois, Icek Ajzen, \& Peter Schmidt. (2015) "Using the theory of planned behavior to identify key beliefs underlying proenvironmental behavior in high-school students: Implications for educational interventions." Journal of Environmental Psychology, 42, 128-138. https://doi.org/10.1016/j.jenvp.2015.03.005

Desfandi, Mirza. (2015). "Mewujudkan masyarakat berkarakter peduli lingkungan melalui program adiwiyata." Social Science Education Journal, 2, (1), 31-37, https://doi.org/10.15408/sd.v2i1.1661

Fatria, E., Putrawan, I.M., \& Artanti, G.D. (2019). "Environment and Commitment, Locus of Control and Intention to Act". Indian Journal of Public Health Research \& Development, 10, (9), 1781-1785. https://doi.org/10.5958/0976-5506.2019.02711.6

Hakim, M.A., Putrawan, I.M., \& Yufiarti. (2019). "The Relationship Between Instructional Leadership, Locus of Control, and Personality with Citizenship Behavior". International Journal of Innovative Technology and Exploring Engineering (IJITEE), 8, (6), 183-187.

Heimlich, Joe E., \& Nicole Ardoin. (2008). "Understanding behavior to understand behavior change: a Literature View." Environmental Education Research, 14, (3), 215-237. https://doi.org/10.1080/13504620802148881 
Hines, J. M., Hungerford, H. R., Tomera, A. N. (1987). Analysis and Synthesis of Research on Responsible Environmental Behavior: A MetaAnalysis. The Journal of Environmental Education, 18, (2), 1-8. https://doi.org/10.1080/00958964.1987.9943482

Huang, Huiping. (2016) Media use, environmental beliefs, self-efficacy, and pro environmental behavior. Journal of Business Research, 69, (6), 22062212. https://doi.org/10.1016/j.jbusres.2015.12.031

Lee, H.T., \& Jan, F.H. (2015). "The influence of recreation experience and environmental attitude on the environmentally responsible behavior of community-based tourists in Taiwan". Journal of Sustainable Tourism, 23, (7), 1-32. https://doi.org/10.1080/09669582.2015.1032298

Levine, Debra Siegel, and Michael J. Strube. (2012). "Environmental Attitudes,Knowledge, Intentions and Behaviors among College Students." Journal of Social Psychology, 152, (3), 308-326. DOI: $\underline{10.1080 / 00224545.2011 .604363}$

Milfont, T.L. \& Duckitt, J. (2010). The environmental attitudes inventory: A valid and reliable measure to assess the structure of environmental attitudes. Journal of Environmental Psychology, 30, (1), 80-94. https://doi.org/10.1016/j.jenvp.2009.09.001

Newhouse, N. (1990). Implications of Attitude and Behavior Research for Environmental Conservation. The Journal of Environmental Education, 22, (1), 26-32. https://doi.org/10.1080/00958964.1990.9943043

Putrawan, I.M. (2017). 'Predicting Students' Responsible Environmental Behavior (REB) Based on Personality, Students' New Environmental Paradigm (NEP) and Naturalistic Intelligence". Advanced Science Letters, 23, (9), 8586-8593. https://doi.org/10.1166/asl.2017.9934

Putrawan, I.M. (2018). "Predicting Environmental Leadership Based on Personality and Its Construct Validity". International Journal of Engineering \& Technology, 7, (4.28), 92-95.

Putrawan, I.M. \& Ananda, R. (2019). “A Mediated Role of Students New Environmental Paradigm (NEP) Between Environmental Personality and Pro-Eco Behavior. Indian Journal of Public Health Research \& Development, $10 \quad$ (1), 322-327. https://doi.org/10.5958/0976$\underline{5506.2019 .00235 .3}$

Putrawan, I.M. \& Ningtyas, L.D. (2019). "The Role of Environmental Leadership and Personality on VBN Model". Indian Journal of Public Health Research \& Development, 10, (9), 1776-1780. https://doi.org/10.5958/0976$\underline{5506.2019 .02710 .4}$ 
Poškus, Mykolas Simas. (2017). "Normative Influence of Pro-Environmental Intentions in Adolescents with Different Personality Types." Current Psychology, 1-14. https://doi.org/10.1007/s12144-017-9759-5

Rhodes, E. R., Courneya, S.K., \& Hayduk, L.A. (2002). "Does Personality Moderate the Theory of Planned Behavior in The Exercise Domain?". Journal of Sport \& Exercise Psychology, 24, (2), 120-132. https://doi.org/10.1123/jsep.24.2.120

Schultz, D. P. \& Schultz, S. E. (2004). Theories of Personality Eighth Edition. California: Wadsworth Publishing. 